\title{
Grey vs. Young Entrepreneurs: Are They Really That Different in Terms of Entrepreneurial Intentions? Empirical Evidence from Italy
}

\author{
Diego Matricano ${ }^{1}$ \\ ${ }^{1}$ Department of Management, Università degli Studi della Campania "Luigi Vanvitelli”, Capua (CE), Italy \\ Correspondence: Diego Matricano, Department of Management, Università degli Studi della Campania "Luigi \\ Vanvitelli”, Corso Gran Priorato di Malta - 81043 Capua (CE), Italy. E-mail: diego.matricano@unicampania.it
}

Received: December 11, 2017

Accepted: January 2, $2018 \quad$ Online Published: January 15, 2018

doi:10.5539/ijbm.v13n2p76

URL: https://doi.org/10.5539/ijbm.v13n2p76

\begin{abstract}
In the past, entrepreneurship was considered a young person's endeavour, since it was a working choice made after graduation. Social and demographic changes occurring over the last decades have totally modified that assumption so that entrepreneurship is now a phenomenon involving third age people (aged 55 or older) as well. Scholars have started investigating the differences between young and grey entrepreneurs. This topic of research has always been considered halfway between psychological and social studies on the one hand and entrepreneurial studies on the other. Without denying the relevance that psychological and social studies have in the field of entrepreneurship, in the present paper the phenomenon of grey entrepreneurship is only investigated according to an entrepreneurial perspective. Thus, predictors of entrepreneurial intentions are only rooted in entrepreneurial literature and refer to intellectual capital. The results, based on data retrieved from Global Entrepreneurship Monitor (GEM) website for Italy in 2013, indicate that grey and young entrepreneurs are not that different regarding intellectual capital affecting their entrepreneurial intentions. This result enriches previous literature about grey entrepreneurs.
\end{abstract}

Keywords: grey, older, senior, entrepreneurs, intellectual capital, entrepreneurial intentions

\section{Introduction}

At a first glance, entrepreneurship seems to only involve young people (Curran \& Blackburn, 2001; Blanchflower, 2004; Weber \& Schaper, 2004; Jamil, Nasah, \& Hassan, 2014). Very often, in fact, high schools, universities and other institutions offer dedicated courses for young would-be entrepreneurs to nurture, improve or modify their entrepreneurial intentions (Gibb, 1993, 1994; Wee, 2004; Matlay, 2005, 2006, 2007; Pittaway and Cope, 2007a, 2007b; Rae, 2007; Fisher, Graham, \& Compeau, 2008; Matricano, 2014, 2017).

However, there is a growing body of evidence and literature that aging people are involved in entrepreneurship as well. This seems mainly due to global population increases, impacting the size of workforce and rate of productivity (Weber \& Schaper, 2004; Beckett \& Frederick, 2011; Backman \& Karlsson, 2013). Consequently, several scholars started investigating entrepreneurship in third age (Singh \& DeNoble, 2003; Lévesque \& Minniti, 2006; Kautonen, Down, \& South, 2008; Kautonen, Tornikoski, \& Kibler, 2011; Kautonen, Down, \& Minniti, 2014) that - by definition - can take place after retirements (Singh \& DeNoble, 2003; Jamil et al., 2014) and involves older entrepreneurs (Curran \& Blackburn, 2001; Karoly \& Zissimopoulos, 2004; Zissimopoulos \& Karoly, 2007; Kerr \& Armstrong-Stassen, 2011; Small, 2012; Zolin, 2015; Usman, Fan, \& Haq, 2016), also called grey entrepreneurs (Weber \& Schaper, 2004; Botham \& Graves, 2009) or senior entrepreneurs (Kautonen, 2013; Maritz, 2015). Even if some differences emerge among these groups (Baucus \& Human, 1994; Blackburn, Hart, \& O'Reilly, 2000; Weber \& Schaper, 2004), they are synonymous in this paper. Older, grey and senior entrepreneurs are considered as 'someone over a certain age who begins their own small or medium-sized enterprises' (Weber \& Schaper, 2004, p. 152).

Most scholars share the same starting point: entrepreneurial intentions of third age entrepreneurs depend on previous experiences (Dyer, 1994). As such, this topic has always been considered halfway between psychological and social studies on the one hand and entrepreneurial studies on the other. Without denying the relevance of psychological and social studies have in the field of entrepreneurship (Matricano, 2015), this paper addresses the phenomenon of grey entrepreneurship from an entrepreneurial perspective only. Thus, to determine whether grey and young entrepreneurs differ regarding their entrepreneurial intentions, predictors for 
entrepreneurial intentions are gleaned from entrepreneurship literature.

According to the above, the paper is structured as it follows. In section two of this paper, the main contributions on older entrepreneurs are recalled and analysed. The review aims to disclose the relevant variables for investigating the phenomenon. The heterogeneity of variables seems to compel scholars to search a new theoretical framework that - according to the recent evolution of entrepreneurship studies - can be related to intellectual capital (section three). Human capital, structural capital, and relational capital are the factors investigated to predict entrepreneurial intentions for each age cohort. In section four, it is argued the choice to utilize secondary data derived from the Global Entrepreneurship Monitor (GEM) website. Regarding 2013 for Italy, the results show that grey and young entrepreneurs are not that different in terms of intellectual capital affecting their entrepreneurial intentions. For both age cohorts, only human capital is relevant, even if the intensity of this variable increases as would-be entrepreneurs age. In the last section, the results are discussed and some suggestions for future research are provided.

\section{Literature Review}

This paper focuses on the entrepreneurial intentions of grey entrepreneurs who, as Backman and Karlsson (2013, pg. 3) argue, 'do not transition from career employment to retirement but to self-employment, which might provide the flexibility in hours and type of work that older workers desire'. As already said, some scholars call them older entrepreneurs (Curran \& Blackburn, 2001; Karoly \& Zissimopoulos, 2004; Zissimopoulos \& Karoly, 2007; Kerr \& Armstrong-Stassen, 2011; Small, 2012; Zolin, 2015; Usman et al., 2016), while other scholars label them as grey entrepreneurs (Weber \& Schaper, 2004; Botham \& Graves, 2009) or senior entrepreneurs (Kautonen, 2013; Maritz, 2015). Even if some differences emerge between the above groups (Baucus \& Human, 1994; Blackburn et al., 2000; Weber \& Schaper, 2004), they are synonymous in this paper. Older, grey and senior entrepreneurs are considered 'someone over a certain age who begins their own small or medium-sized enterprises' (Weber \& Schaper, 2004, p. 152).

More than twenty years ago, Dyer (1994) authored one of the earliest papers on the entrepreneurial intentions of grey entrepreneurs. Dyer (ibidem) investigated whether previous working experiences could affect individual intentions and impact entrepreneurial behaviour. Shane (2000) reinforced the idea that the recognition of entrepreneurial opportunities depends on previous work experience, thus leading other scholars to investigate the factors that influence older entrepreneurs. Carr and Sequeira (2007), for example, tested and confirmed the influence of previous working experiences and entrepreneurial intentions.

As noted by Backman and Karlsson (2013), despite the interest in entrepreneurship, scholars investigating grey entrepreneurship have often used an approach rooted in psychological and social studies (Weber \& Schaper, 2004). Jamil et al. (2014) maintained that two models could be used to investigate the entrepreneurial intentions of grey entrepreneurs: the theory of planned behaviour (TPB), as proposed by Ajzen (1991), and Shapero's model of entrepreneurial event (1982). Entrepreneurship scholars tend to prefer the TPB. Kautonen et al. (2011) used this model to test the impact of perceived age norms. Alternatively, Kautonen, Luoto and Tornikoski (2010) addressed their attention toward the role previously held by older entrepreneurs. They tested whether previous roles of industrial workers, employees in the public sector or small business affected entrepreneurial intentions in third age. They based their analysis on Ajzan's TPB (1991). Both studies demonstrate the strong influence that psychological and sociological studies have on grey entrepreneurship literature.

Lévesque and Minniti (2006) proposed another model to explain how individuals allocate their time between work and leisure, waged labour and entrepreneurship. This model was modified and applied by Kautonen et al. (2014) regarding grey entrepreneurship.

Unquestionalby, both the psychological and sociological approaches have enriched this field of research, but it seems that the phenomenon must also be properly framed from an entrepreneurial point of view. In fact, over the years, scholars have become aware that entrepreneurial factors - which can be combined or not with psychological and social factors - need to be considered when investing grey entrepreneurship. In this vein, several studies have investigated entrepreneurial variables on the topic.

First, Beckett and Frederick (2011) tried to synthesize the dynamics and motivations of older entrepreneurs by highlighting the differences between business and social entrepreneurship by relying on entrepreneurial studies. Botham and Graves (2009) listed the personal characteristics of grey entrepreneurs and the business characteristics. As such, scholars have underlined that older entrepreneurs are less likely to engage in high-tech industries, but instead tend to launch improved products into markets. They prefer financial, professional, business and agricultural industries to retail and consumers services since they aim to 'balance work with leisure' (ibidem, pg. 52). Eventually, Curran and Blackburn (2011) demonstrated the main reasons older people do not 
prefer to be entrepreneurs. The missing guarantee of income (an economic aspect) and the idea of feeling too old (a psychological one) are at the top of the list.

Backman and Karlsson (2013) considered a list of factors that influence the entrepreneurial intentions of grey entrepreneurs. The first group of factors included human capital, financial capital, the role of networks and previous experience. The second group of factors was related to risk propensity and level of education. In their view, these economic aspects contributed to a clearer understanding of the phenomenon. Zolin (2015) focused on the effect of industry and start-up experience, hours worked and financial assets to test if grey entrepreneurs were more inclined to work harder or smarter. Kautonen (2013) addressed three main factors: lack of financial support, complexity of administrative procedures and lack of information. Kautonen et al. (2014) considered the influence of the parents' occupations, financial support and the risk of failure. Eventually, Singh and DeNoble (2003) examined entrepreneurial paths of older entrepreneurs that can be constrained, rational, or reluctant.

Even if each of these contributions advanced studies on grey entrepreneurship, the heterogeneity of variables has not framed the phenomenon in a clear or comprehensive way. For this reason, a framework rooted in entrepreneurial literature needs to be utilized.

\section{Theoretical Framework and Research Hypotheses}

Several scholars (Kautonen et al., 2008; Usman et al., 2016) proposed using a framework that included push and pull factors to test the entrepreneurial intentions of grey entrepreneurs. Pull factors are those that positively affect a phenomenon, while push factors negatively affect it. What emerges from some studies (Curran \& Blackburn, 2001; Zissimopoulos \& Karoly, 2007) was the difficulty to classify each factor as either push or pull for grey entrepreneurs. Psychological aspects can modify individual perceptions so that some factors, like health (Curran \& Blackburn, 2001), can both push and pull. This complicates the ongoing of dedicated studies.

For that reason, another framework - preferably rooted in entrepreneurial studies - is required. In recent years, one of the most used frameworks for investigating entrepreneurial intentions is related to intellectual capital (IC). Broadly, IC represents the intangible assets companies leverage for their competitive advantage (Bontis, 1996, 1998, 2001; Sveiby, 1997; Petty \& Guthrie, 2000; Hormiga, Batista-Canino, \& Sánchez-Medina, 2011). Some entrepreneurship scholars referred to IC regarding start-ups (Peña, 2002; Hayton, 2005; Hormiga et al., 2011; Link \& Ruhm, 2011; Musteen \& Ahsan, 2013) and provided useful implications for investigating entrepreneurial intentions as well (Matricano, 2016).

IC is made up of human capital, structural capital, and relational capital (Sullivan, 1999; Brennan \& Connell, 2000; Petty \& Guthrie, 2000; Sanchez, Chamichade, \& Olea, 2000; Roos, Brainbridge, \& Jacobsen, 2001; Peña, 2002; Kaufmann \& Schneider, 2004; Boedker, Guthrie, \& Cuganesan, 2005; Hormiga et al., 2011; Musteen \& Ahsan, 2013). By human capital, management scholars refer to intellectual agility, knowledge and personal capabilities (Bontis, 1998; Bontis, Dragonetti, Jacobsen, \& Roos, 1999; Bontis, Keow, \& Richardson, 2000; Khalique, Bontis, Shaari, \& Isa, 2015; Subramaniam \& Youndt, 2005; Montequín, Fernández, Cabal, \& Gutierrez, 2006; Tovstiga \& Tulugurova, 2007; Wu, Chang, \& Chen, 2008; Hsu \& Fang, 2009). These features differentiate managers and non-managers, and talented from unsuccessful workers. Similarly, entrepreneurship scholars argue that these characteristics help distinguish between entrepreneurs and non-entrepreneurs (MacMillan, 1986; Low \& MacMillan, 1988; McGrath \& MacMillan, 2000; Ucbasaran, Wright, \& Westhead, 2003; Ucbasaran, Westhead, \& Wright, 2006; Westhead, Ucbasaran, \& Wright, 2005).

Structural capital refers to the competences that companies acquire, such as patents or organizational culture (Sveiby, 1997; Bontis et al., 2000; Subramaniam \& Youndt, 2005; Cabrita \& Bontis, 2008; Wu et al., 2008; Hsu \& Fang, 2009; Hormiga et al., 2011). These competences stand independent of the people working in those companies. Entrepreneurship scholars translate the concept of structural capital into entrepreneurial opportunities. Despite different proposals (Shane, 2000; Sarasvathy, Dew, Velamuri, \& Venkataraman, 2005; Alvarez \& Barney, 2008), McMullen and Shepherd (2006) argue that some entrepreneurial opportunities are third-person opportunities since they are not linked to the person identifying them or to the context they are in. These opportunities exist by themselves and can represent structural capital in entrepreneurial studies.

Lastly, relational capital refers to networking activities initiated and manged by companies (Bontis, 2001; Montequín, Fernández, Cabal, \& Gutierrez, 2006; Cabrita \& Bontis, 2008; Wu et al., 2008; Hsu \& Fang, 2009). These activities are valuable if they provide missing resources (both tangible and intangible). Also, entrepreneurship scholars have investigated and confirmed the relevance of networking activities (Birley, 1985; Aldrich \& Zimmer, 1986; Johannisson, 1986, 1988; Starr \& MacMillan, 1990). In the field of entrepreneurial studies, scholars studied the involvement of relatives, friends or previous employers in networks (Greve, 1995; Greve \& Salaff, 2003) due to the effect of their trusting relationships (Johannisson, 1988; Larson \& Starr, 1993; 
Greve, 1995; Smith \& Lohrke, 2008).

The relevance that human, structural and relational capital assume in entrepreneurial studies suggests they can affect entrepreneurial intentions of would-be entrepreneurs (Krueger, Reilly, \& Carsrud, 2000; Baron, 2004; Lee $\&$ Wong, 2004) and thus, comprise the theoretical framework in this paper (Table 1).

Table 1. The Theoretical Framework.

\begin{tabular}{ccc}
\hline Independent variables & & Dependent variable \\
\hline Human capital & $\rightarrow$ & Start-up intentions of \\
Structural capital & $\rightarrow$ & would-be entrepreneurs \\
Relational capital & $\rightarrow$ & \\
\hline
\end{tabular}

To test if grey and young entrepreneurs differ in term of IC regarding their entrepreneurial intentions, human, structural and relational capital (considered as predictors of entrepreneurial intentions) are tested through three research hypotheses. Each one has corresponding rival hypotheses.

As for human capital (H1), the rival hypotheses offered herein are:

H1a: Human capital affects the start-up intentions of younger entrepreneurs rather than older entrepreneurs.

H1b: Human capital affects the start-up intentions of older entrepreneurs rather than younger entrepreneurs.

In reference to structural capital (H2), the rival hypotheses offered herein argue:

H2a: Structural capital affects the start-up intentions of younger entrepreneurs rather than older entrepreneurs.

H2b: Structural capital affects the start-up intentions of older entrepreneurs rather than younger entrepreneurs.

Regarding relational capital (H3), the rival hypotheses offered herein predict:

H3a: Relational capital affects the start-up intentions of younger entrepreneurs rather than older entrepreneurs.

H3b: Relational capital affects the start-up intentions of older entrepreneurs rather than younger entrepreneurs.

\section{Methodology, Data and Results}

At first, it is important to define the geographical boundaries of the research. Even though some cross-border studies were carried out for international comparisons of the phenomenon - Beckett \& Frederick (2011), for example, considered GEM data from 79 countries, while Kautonen et al. (2014) investigated the phenomenon over 27 European countries - management scholars prefer conducting their research in reference to a single country. This guarantees that macroeconomic and cultural variables are the same, thus reinforcing the economic concept of ceteris paribus. In the same vein, some scholars focused on European countries. Kautonen et al. $(2010,2011)$ investigated grey entrepreneurship in Finland, Backman and Karlsson (2013) investigated the Swedish case and Curran and Blackburn (2001), Parker and Rougier (2007), Small (2012), and Kautonen (2013) investigated the phenomenon in the United Kingdom. Other scholars chose non-European countries. Rogoff (2007), for example, investigated the phenomenon in the United States, Jamil et al. (2014) analysed the case in Malaysia, Usman et al. (2016) analysed Pakistan, and Maritz (2015) investigated the phenomenon in Australia. However - to the knowledge of the author - a study about grey entrepreneurship in Italy is still missing, which is why this research focuses only on the Italian context.

The data for this study are retrieved from the GEM website and refere to 2013 (the last data-set available on the website). The predictors (human, structural and relational capital) and the dependent variable (the start-up intentions) are expressed by some proxies and catalogued as binomial. Thus the binomial logistic regression model is used. All the variables are labelled as 1 if the interviewee leverages human, structural and relational capital and shows entrepreneurial intentions. Otherwise they are labelled as 0 . This is 'Model A' to be tested.

Before proceeding with statistical elaborations, it is appropriate to wonder about robustness of results. Firstly, it is important to check the amount of available responses. Secondary data retrieved from GEM website guarantee a numerically significant dataset (2,052 responses), which enhances robustness of this study. Respondents are divided into three age cohorts: 18 to 34 years old, 35 to 54 years old, and older than 55 . The number of respondents for each cohort is displayed in Table 2. 
Table 2. Samples of Respondents by Age Cohorts.

\begin{tabular}{cc}
\hline Age cohort & Sample size \\
\hline $18-34$ years old & 601 \\
$35-54$ years old & 1,031 \\
more than 55 years old & 420 \\
Total & 2,052 \\
\hline
\end{tabular}

Secondly, it is important to introduce some control variables to ensure the robustness of the results. Control variables are linked to the dependent variable (i.e. entrepreneurial intentions) but from another perspective. The control variables in this study are the idea that entrepreneurship is a desirable career choice and the level of competition. They both affect entrepreneurial intentions but are not related to intellectual capital. Also, the control variables are binomial, and are thus labelled as 1 if the respondents consider entrepreneurship as a desirable career choice and perceive a high level of competition. Otherwise, they are labelled as 0 . The model, including control variables, is 'Model B'.

The last aspect to wonder about is collinearity. According to statisticians, some collinearity statistics - such as tolerance and variance inflation factor (VIF) - and some collinearity diagnostics (condition index) need to be calculated preliminarily. In Table 3, collinearity statistics (values of tolerance) are shown.

Table 3. Tolerance of Models A and B by Age Cohorts.

\begin{tabular}{lcccccc}
\hline & \multicolumn{2}{c}{$18-34$ years old } & \multicolumn{2}{c}{$35-54$ years old } & \multicolumn{2}{c}{ aged 55 or older } \\
\hline Model A & Model B & Model A & Model B & Model A & Model B \\
Human capital & 0.972 & 0.954 & 0.951 & 0.930 & 0.942 & 0.910 \\
Structural capital & 0.963 & 0.963 & 0.969 & 0.965 & 0.973 & 0.969 \\
Relational capital & 0.958 & 0.918 & 0.960 & 0.956 & 0.926 & 0.911 \\
Carrier choice & & 0.987 & & 0.989 & & 0.988 \\
Level of competition & & 0.934 & & 0.975 & & 0.948 \\
\hline
\end{tabular}

Theoretically, values of tolerance are expected to be greater than 0.50 . Each value in Table 3 respects the above threshold and thus tolerance does not represent a problem in the proposed models. In Table 4, collinearity statistics (values of VIF) are shown.

Table 4. VIF of Models A and B by Age Cohorts.

\begin{tabular}{lcccccc}
\hline & \multicolumn{2}{c}{$18-34$ years old } & \multicolumn{2}{c}{$35-54$ years old } & \multicolumn{2}{c}{ aged 55 or older } \\
\hline Model A & Model B & Model A & Model B & Model A & Model B \\
Human capital & 1.029 & 1.048 & 1.052 & 1.075 & 1.062 & 1.099 \\
Structural capital & 1.038 & 1.038 & 1.032 & 1.036 & 1.028 & 1.032 \\
Relational capital & 1.043 & 1.089 & 1.042 & 1.046 & 1.080 & 1.098 \\
Carrier choice & & 1.013 & & 1.011 & & 1.012 \\
Level of competition & & 1.071 & & 1.026 & & 1.054 \\
\hline
\end{tabular}

Theoretically, values of VIF are expected to be less than 2. Each of the values in Table 4 respects the above threshold and thus VIF does not represent a problem in the proposed models. Eventually, to be sure there is no collinearity among independent variables, it is appropriate to consider the values of condition index (Table 5). 
Table 5. Condition Index of Models A and B by Age Cohorts.

\begin{tabular}{lcccccc}
\hline & \multicolumn{2}{c}{$18-34$ years old } & \multicolumn{2}{c}{$35-54$ years old } & \multicolumn{2}{c}{ aged 55 or older } \\
\hline & Model A & Model B & Model A & Model B & Model A & Model B \\
Constant & 1.000 & 1.000 & 1.000 & 1.000 & 1.000 & 1.000 \\
Human capital & 2.228 & 2.109 & 2.247 & 1.949 & 2.029 & 2.016 \\
Structural capital & 1.786 & 1.958 & 1.823 & 1.943 & 1.816 & 1.838 \\
Relational capital & 1.759 & 1.701 & 1.703 & 1.724 & 1.631 & 1.635 \\
Carrier choice & & 2.257 & & 2.273 & & 2.147 \\
Level of competition & & 4.038 & & 3.559 & & 3.683 \\
\hline
\end{tabular}

Values of condition index need proper evaluation. If they are higher than 30, they disclosed a strong collinearity. If they are between 15 and 30, then they reveal a suspected collinearity. Eventually, if they are less than 15, they do not show any collinearity among predictors. Values of condition index included in Table 5 are less than 5 and thus it is possible to argue there is no collinearity among independent variables. At this stage, binomial logistic regression models are calculated. Elaborations are based on the forward Wald approach (see Table 6).

Table 6. Estimated Binomial Logistic Regression Models by Age Cohorts.

\begin{tabular}{|c|c|c|c|c|c|c|}
\hline & \multicolumn{2}{|c|}{$18-34$ years old } & \multicolumn{2}{|c|}{$35-54$ years old } & \multicolumn{2}{|c|}{ aged 55 or older } \\
\hline Constant & $\begin{array}{c}\text { Model A } \\
\mathbf{0 . 1 2 3} \\
(\mathbf{0 . 0 0 0 )}\end{array}$ & $\begin{array}{c}\text { Model B } \\
\mathbf{0 . 1 1 8} \\
(\mathbf{0 . 0 0 0 )}\end{array}$ & $\begin{array}{c}\text { Model A } \\
\mathbf{0 . 0 3 3} \\
(\mathbf{0 . 0 0 0 )}\end{array}$ & $\begin{array}{c}\text { Model B } \\
\mathbf{0 . 0 2 2} \\
(\mathbf{0 . 0 0 0 )}\end{array}$ & $\begin{array}{c}\text { Model A } \\
\mathbf{0 . 0 2 5} \\
(\mathbf{0 . 0 0 0 )}\end{array}$ & $\begin{array}{c}\text { Model B } \\
\mathbf{0 . 0 0 8} \\
(\mathbf{0 . 0 0 0 )}\end{array}$ \\
\hline Predictors & & & & & & \\
\hline Human capital & $\begin{array}{c}3.679 \\
(0.000)\end{array}$ & $\begin{array}{c}3.387 \\
(0.000)\end{array}$ & $\begin{array}{c}5.876 \\
(0.000)\end{array}$ & $\begin{array}{c}5.573 \\
(0.000)\end{array}$ & $\begin{array}{c}8.154 \\
(0.000)\end{array}$ & $\begin{array}{c}5.894 \\
(0.000)\end{array}$ \\
\hline Structural capital & $\begin{array}{c}0.097 \\
(0.755)\end{array}$ & $\begin{array}{c}0.028 \\
(0.867)\end{array}$ & $\begin{array}{c}1.951 \\
(0.009)\end{array}$ & $\begin{array}{c}1.936 \\
(0.011)\end{array}$ & $\begin{array}{c}0.018 \\
(0.8939\end{array}$ & $\begin{array}{c}0.147 \\
(0.702)\end{array}$ \\
\hline Relational capital & $\begin{array}{c}0.002 \\
(0.967)\end{array}$ & $\begin{array}{c}0.661 \\
(0.416)\end{array}$ & $\begin{array}{c}1.722 \\
(0.032)\end{array}$ & $\begin{array}{c}3.743 \\
(0.053)\end{array}$ & $\begin{array}{c}2.037 \\
(0.153)\end{array}$ & $\begin{array}{c}0.582 \\
(0.445)\end{array}$ \\
\hline Control variables & & & & & & \\
\hline Carrier choice & & $\begin{array}{c}0.559 \\
(0.454)\end{array}$ & & $\begin{array}{c}2.105 \\
(0.004)\end{array}$ & & $\begin{array}{c}4.325 \\
(0.040)\end{array}$ \\
\hline Level of competition & & $\begin{array}{c}4.375 \\
(0.002)\end{array}$ & & $\begin{array}{c}2.078 \\
(0.002)\end{array}$ & & $\begin{array}{c}4.754 \\
(0.002)\end{array}$ \\
\hline Model diagnostics & & & & & & \\
\hline Number of cases & 601 & 601 & 1,031 & 1,031 & 420 & 420 \\
\hline $\begin{array}{l}\text { Percentage of correct } \\
\text { predictions }\end{array}$ & $83.2 \%$ & $82.7 \%$ & $90.6 \%$ & $91.0 \%$ & $94.3 \%$ & $94.3 \%$ \\
\hline$\chi^{2}$ of Omnibus test & 0.000 & 0.000 & 0.000 & 0.000 & 0.000 & 0.000 \\
\hline $\begin{array}{l}\text { Degree of freedom of } \\
\text { Omnibus test }\end{array}$ & 1 & 2 & 3 & 4 & 1 & 3 \\
\hline Nagelkerke $R^{2}$ (pseudo ${ }^{2}$ ) & 0.090 & 0.114 & 0.172 & 0.200 & 0.151 & 0.248 \\
\hline
\end{tabular}

\section{Discussion and Conclusions}

By leveraging data retrieved from the GEM website, an empirical investigation for Italy in 2013 has been conducted about intellectual capital affecting entrepreneurial intentions of young and grey people. The results, achieved using estimated binomial logistic regression models, are twofold.

First, empirical evidence (related to Model B, with control variables) shows that grey and young entrepreneurs are not that different. Regarding the three sub-components of IC, human capital is the only relevant factor for either of them. Neither structural nor relational capital is. The result is intriguing if attention is also paid over middle-aged entrepreneurs (35-54 years old) whose structural capital - instead - affects entrepreneurial intentions as well. This evidence discloses that young entrepreneurs only leverage human capital. When they become middle-aged, they leverage human and structural capitals. Finally, when entrepreneurs are 55 or older, 
they only leverage human capital. Therefore, grey and young entrepreneurs are not that different.

Secondly, empirical evidence also suggests that a difference exists between grey and young entrepreneurs. The human capital held by grey entrepreneurs affects their entrepreneurial intentions more than young entrepreneurs (respectively, the values were 5.894 and 3.679 so only H1b is confirmed). This means that intellectual agility, knowledge and personal capabilities - which are expected to be more developed in grey entrepreneurs - have a significant effect on entrepreneurial intentions. This result is aligned with some previous studies. According to Kautonen et al. (2010), some differences exist between young and third age entrepreneurs and, in particular, according to Zolin (2015), senior entrepreneurs display an exceptionally shrewd approach to entrepreneurship.

Despite some limitations that necessarily occur when carrying out empirical studies (the main limitations in this case stem from the use of secondary data and with the impossibility to disclose specific insights from the results), this paper can offer some hints for future research. Regarding the Italian case, grey and young entrepreneurs are not that different. They both leverage human capital, although the impact of human capital on entrepreneurial intentions increased as entrepreneurs grew older. Further investigations should be carried out to investigate the causes of this difference. Experience on field might be considered one of the main causes (MacMillan, 1986) but more focused research should be conducted to demonstrate this.

Hopefully, forthcoming researches will be rooted in entrepreneurial literature and enriched by psychological and sociological factors in order to provide more insights about young and grey entrepreneurs, their similarities and differences.

\section{References}

Ajzen, I. (1991). The theory of planned behavior. Organizational Behavior and Human Decision Processes, 50(2), 179-211. https://doi.org/10.1016/0749-5978(91)90020-T

Aldrich, H. E., \& Zimmer, C. (1986). Entrepreneurship through social networks. In H. E. Aldrich (Ed.), Population Perspective on Organizations (pp. 13-28), Uppsala, SW: Acta Universitatis Upaliensis.

Alvarez, S. A., \& Barney, J. B. (2008). Opportunities, organizations, and entrepreneurship. Strategic Entrepreneurship Journal, 2(3), 171-173. https://doi.org/10.1002/sej.52

Backman, M., \& Karlsson, C. (2013). Who says life is over after 55? Entrepreneurship and an aging population. CESIS - Centre of Excellence for Science and Innovation Studies. Paper N. 325. Retrived from http://www.cesis.se.

Baron, R. A. (2004). The cognitive perspective: a valuable tool for answering entrepreneurship's basis why $\begin{array}{lllll}\text { question. Journal of } & \text { Business }\end{array}$ https://doi.org/10.1016/S0883-9026(03)00008-9

Baucus, D. A., \& Human, S. E. (1994). Second-career entrepreneurs: A multiple case study analysis of entrepreneurial processes and antecedent variables. Entrepreneurship: Theory and Practice, 19(2), 41-72. https://doi.org/10.1177/104225879501900204

Beckett, R. C., \& Frederick, H. (2011). Grandpa as an entrepreneur: Population dynamics of social and business entrepreneurship, an exploratory analysis. In IICIES 2011: Creative and cultural entrepreneurship in the new era: Proceedings of the 2011 Indonesia International Conference on Innovation, Entrepreneurship, and Small Business (pp. 717-726). IICIES (January).

Birley, S. (1985). The role of networks in the entrepreneurial process. Journal of Business Venturing, 1(1), 107-117. https://doi.org/10.1016/0883-9026(85)90010-2

Blackburn, R., Hart, M., \& O'Reilly, M. (2000). Entrepreneurship in the third age: new dawn or misplaced expectations? In 23rd ISBA National Small Firms Policy and Research Conference (pp. 1-17). ISBA (November).

Blanchflower, D. G. (2004). Self-employment: more may not be better. Swedish Economic Policy Review, 11(2), 15-74. https://doi.org/10.3386/w10286

Boedker, C., Guthrie, J. and Cuganesan, S. (2005). An integrated framework for visualizing intellectual capital. Journal of Intellectual Capital, 6(4), 510-527. https://doi.org/10.1108/14691930510628799

Bontis, N., Dragonetti, N.C., Jacobsen, K., \& Roos, G. (1999). The knowledge toolbox: a review of the tools available to measure and manage intangible resources. European Management Journal, 17(4), 391-402. https://doi.org/10.1016/S0263-2373(99)00019-5

Bontis, N., Keow, W. C. C., \& Richardson, S. (2000). Intellectual capital and business performance in 
Malaysian industries. Journal of Intellectual Capital, 1(1), 85-100. https://doi.org/10.1108/14691930010324188

Bontis, N. (1996). There's a price on your head: managing intellectual capital strategically. Business Quarterly, 60(4), 40-47.

Bontis, N. (1998). Intellectual capital: an exploratory study that develops measures and models. Management Decision, 36(2), 63-76. https://doi.org/10.1108/00251749810204142

Bontis, N. (2001). Assessing knowledge assets: a review of the models used to measure intellectual capital. International Journal of Management Reviews, 3(1), 41-60. https://doi.org/10.1111/1468-2370.00053

Botham, R., \& Graves, A. (2009). The Grey Economy: How Third Age Entrepreneurs Are Contributing to Growth. London: NESTA Research report.

Brennan, N., \& Connell, B. (2000). Intellectual capital: current issues and policy implication. Journal of Intellectual Capital, 1(3), 206-240. https://doi.org/10.1108/14691930010350792

Cabrita, M. D. R., \& Bontis, N. (2008). Intellectual capital and business performance in the Portuguese banking industry. International Journal of Technology Management, 43(1-3), 212-237. https://doi.org/10.1504/IJTM.2008.019416

Carr, J. C., \& Sequeira, J. M. (2007). Prior family business exposure as intergenerational influence and entrepreneurial intent: A theory of planned behavior approach. Journal of Business Research, 60(10), 1090-1098. https://doi.org/10.1016/j.jbusres.2006.12.016

Curran, J., \& Blackburn, R. A. (2001). Older people and the enterprise society: age and self-employment propensities. Work, Employment and Society, 15(4), 889-902. https://doi.org/10.1177/095001701400438279

Dyer Jr, W. G. (1994). Toward a theory of entrepreneurial careers. Entrepreneurship: Theory and Practice, 19(2), 7-22. https://doi.org/10.1177/104225879501900202

Fisher, S. L., Graham, M. E., \& Compeau, M. (2008). Starting from scratch: Understanding the learning outcomes of undergraduate entrepreneurship education. In: R. T. Harrison \& C. Leitch (Eds.), Entrepreneurial Learning: Conceptual Frameworks and Applications, London, UK: Routledge.

Gibb, A. A. (1993). The enterprise culture and education: Understanding enterprise culture and its links with small business, entrepreneurship and wider educational goals. International Small Business Journal 11(3), 11-34. https://doi.org/10.1177/026624269301100301

Gibb, A. A. (1994). Do we really teach small business the way we should. Journal of Small Business and Entrepreneurship 11(2), 11-28. https://doi.org/10.1080/08276331.1994.10600453

Greve, A. (1995). Networks and entrepreneurship. An analysis of social relations, occupational background, and the use of contacts during the establishment process. Scandinavian Journal of Management, 11(1),1-24. https://doi.org/10.1016/0956-5221(94)00026-E

Greve, A., \& Salaff, J. W. (2003). Social networks and entrepreneurship. Entrepreneurship: Theory and Practice, 28(1), 1-22. https://doi.org/10.1111/1540-8520.00029

Hayton, J. C. (2005). Competing in the new economy: the effect of intellectual capital on corporate entrepreneurship in high-technology new ventures. $R \& D$ Management, 35(2), 137-155. https://doi.org/10.1111/j.1467-9310.2005.00379.x

Hormiga, E., Batista-Canino, R. M., \& Sánchez-Medina, A. (2011). The role of intellectual capital in the success of new ventures. International Entrepreneurship and Management Journal, 7(1), 71-92. https://doi.org/10.1007/s11365-010-0139-y

Hsu, Y. H., \& Fang, W. (2009). Intellectual capital and new product development performance: the mediating role of organizational learning capability. Technological Forecasting and Social Change, 76(5), 664-677. https://doi.org/10.1016/j.techfore.2008.03.012

Jamil, N., Nasah, C. R. J., \& Hassan, Z. (2014). The feasibility of entrepreneurship after retirement. Malaysian Journal of Business and Economics (MJBE), 1(1), 19-33.

Johannisson, B. (1986). Network strategies: management technology for entrepreneurship and change. International Small Business Journal, 5(1), 19-30. https://doi.org/10.1177/026624268600500102

Johannisson, B. (1988). Business formation: a network approach. Scandinavian Journal of Management, 
4(3-4), 83-99. https://doi.org/10.1016/0956-5221(88)90002-4

Karoly, L. A., \& Zissimopoulos, J. (2004). Self-employment among older US workers. Monthly Labor Review, 127(7), 24-47.

Kaufmann, L., \& Schneider, Y. (2004). Intangibles: a synthesis of current research. Journal of Intellectual Capital, 5(3), 366-388. https://doi.org/10.1108/14691930410550354

Kautonen, T. (2013). Senior Entrepreneurship. Paper for the OECD Centre for Entrepreneurship, SMEs and Local Development.

Kautonen, T., Down, S., \& Minniti, M. (2014). Ageing and entrepreneurial preferences. Small Business Economics, 42(3), 579-594. https://doi.org/10.1007/s11187-013-9489-5

Kautonen, T., Down, S., \& South, L. (2008). Enterprise support for older entrepreneurs: the case of PRIME in the UK. International Journal of Entrepreneurial Behavior \& Research, 14(2), 85-101. https://doi.org/10.1108/13552550810863071

Kautonen, T., Luoto, S., \& Tornikoski, E. T. (2010). Influence of work history on entrepreneurial intentions in 'prime age'and 'third age': A preliminary study. International Small Business Journal, 28(6), 583-601. https://doi.org/10.1177/0266242610368592

Kautonen, T., Tornikoski, E. T., \& Kibler, E. (2011). Entrepreneurial intentions in the third age: the impact of perceived age norms. Small business economics, 37(2), 219-234. https://doi.org/10.1007/s11187-009-9238-y

Kerr, G., \& Armstrong-Stassen, M. (2011). The bridge to retirement: older workers' engagement in post-career entrepreneurship and wage-and-salary employment. The Journal of Entrepreneurship, 20(1), 55-76. https://doi.org/10.1177/097135571002000103

Khalique, M., Bontis, N., Shaari, J. A. N., \& Isa, A. H. B. (2015). Intellectual capital in small and medium enterprises in Pakistan. Journal of Intellectual Capital, 16(1), 224-238. https://doi.org/10.1108/JIC-01-2014-0014

Krueger, N. F. Jr, Reilly, M. D., \& Carsrud, A. L. (2000). Competing models of entrepreneurial intentions. Journal of Business Venturing, 15(5-6), 411-432. https://doi.org/10.1016/S0883-9026(98)00033-0

Larson, A., \& Starr, J. A. (1993). A network model of organization formation. Entrepreneurship: Theory and Practice, 17(2), 5-16.

Lee, S. H., \& Wong, P. K. (2004). An exploratory study of technopreneurial intentions: a career anchor perspective. Journal of Business Venturing, 19(1), 7-28. https://doi.org/10.1016/S0883-9026(02)00112-X

Lévesque, M., \& Minniti, M. (2006). The effect of aging on entrepreneurial behavior. Journal of Business Venturing, 21(2), 177-194. https://doi.org/10.1016/j.jbusvent.2005.04.003

Link, A. N., \& Ruhm, C. J. (2011). Public knowledge, private knowledge: the intellectual capital of entrepreneurs. Small Business Economics, 36(1), 1-14. https://doi.org/10.1007/s11187-009-9179-5

Low, M. B., \& MacMillan, I. C. (1988). Entrepreneurship: past research and future challenges. Journal of Management, 14(2), 139-162. https://doi.org/10.1177/014920638801400202

MacMillan, I. C. (1986). To really know about entrepreneurship, let's study habitual entrepreneur. Journal of Business Venturing, 1(3), 241-243.

Maritz, A. (2015). Senior entrepreneurship in Australia: an exploratory approach. International Journal of Organizational Innovation (Online), 7(3), 6-23.

Matlay, H. (2005). Researching entrepreneurship and education. Part 1: What is entrepreneurship and does it matter? Education + Training, 47(8), 665-677. https://doi.org/10.1108/00400910510633198

Matlay, H. (2006). Researching entrepreneurship and education. Part 2: What is entrepreneurship and does it matter? Education + Training, 48(8), 704-718. https://doi.org/10.1108/00400910610710119

Matlay, H. (2007). International perspectives on entrepreneurship education: Introduction. Industry and Higher Education, 21(6): 385-386. https://doi.org/10.1108/ET-09-2014-0113

Matricano, D. (2014). Entrepreneurial training: a comparative study across fifteen European countries. Industry and Higher Education, 28(5), 311-330. https://doi.org/10.5367/ihe.2014.0221

Matricano, D. (2015). Lo Studio dell'Imprenditorialità. Un Approccio di Indagine Multidimensionale. Roma, IT: 
Carocci Editore.

Matricano, D. (2016). The impact of intellectual capital on start-up expectations. Journal of Intellectual Capital, 17(4), 654-674. https://doi.org/10.1108/JIC-04-2016-0040

Matricano, D. (2017). Can policymakers improve the effectiveness of entrepreneurship training programmes? Evidence from Italy. Industry and Higher Education, 31(1), 51-61. https://doi.org/10.1177/0950422216684071

McGrath, R. G., \& MacMillan, I. C. (2000). The Entrepreneurial Mindset. Boston, MA: Harvard Business School Press.

McMullen, J. S., \& Shepherd, D. (2006). Entrepreneurial action and the role of uncertainty in the theory of the entrepreneur. Academy of Management Review, 31(1), 132-152. https://doi.org/10.5465/AMR.2006.19379628

Montequín, V. R., Fernández, F. O., Cabal., V.A., \& Gutierrez, N. R. (2006). An integrated framework for intellectual capital measurement and knowledge management implementation in small and medium-sized enterprises. Journal of Information Science, 32(6), 525-538. https://doi.org/10.1177/0165551506067127

Musteen, M., \& Ahsan, M. (2013). Beyond cost: the role of intellectual capital in off-shoring and innovation in young firms. Entrepreneurship: Theory and Practice, 37(2), 421-434. https://doi.org/10.1111/j.1540-6520.2011.00477.x

Parker, S. C., \& Rougier, J. C. (2007). The retirement behaviour of the self-employed in Britain. Applied Economics, 39(6), 697-713. https://doi.org/10.1080/00036840500447807

Peña, I. (2002). Intellectual capital and business start up success. Journal of Intellectual Capital, 3(2), 180-198. https://doi.org/10.1108/14691930210424761

Petty, R., \& Guthrie, J. (2000). Intellectual capital literature review: measurement, reporting and management. Journal of Intellectual Capital, 1(2), 155-176. https://doi.org/10.1108/14691930010348731

Pittaway, L., \& Cope, J. (2007a). Entrepreneurship education: A systematic review of the evidence. International Small Business Journal, 25(5), 479-510. https://doi.org/10.1177/0266242607080656

Pittaway, L., \& Cope, J. (2007b). Simulating entrepreneurial learning: Integrating experiential and collaborative approaches to learning. Management Learning, 38(2), 211-233. https://doi.org/10.1177/1350507607075776

Rae, D. (2007). Achieving business focus: Promoting the entrepreneurial management capabilities of owner-managers. Industry and Higher Education, 21(6), 415-426. https://doi.org/10.5367/000000007783099773

Rogoff, E. (2007). Opportunities for entrepreneurship in later life. Generations, 31(1), 90-95.

Roos, G., Brainbridge, A., \& Jacobsen, K. (2001). Intellectual capital as a strategic tool. Strategy \& Leadership, 29(4), 21-26. https://doi.org/10.1108/10878570110400116

Sanchez, P., Chamichade, C., \& Olea, M. (2000). Management of intangibles: the role of strategy, industry structure and entrepreneur. Journal of Intellectual Capital, 1(4), 188-209.

Sarasvathy, S. D., Dew, N., Velamuri, S. R., \& Venkataraman, S. (2005). Three views of entrepreneurial opportunity. In Z. J. Acs \& D. B. Audretsch (Eds.), Handbook of Entrepreneurship Research: An Interdisciplinary Survey and Introduction, New York, USA: Springer (pp. 141-160).

Shane, S. (2000). Prior knowledge and the discovery of entrepreneurial opportunities. Organization Science, 11(4), 448-469. https://doi.org/10.1287/orsc.11.4.448.14602

Shapero, A. (1982). Social dimensions of entrepreneurship. In C. Kent, D. Sexton, \& K. Vesper (Eds.), The Encyclopedia of Entrepreneurship. Englewood Cliffs: Prentice Hall (pp. 72-90).

Singh, G., \& DeNoble, A. (2003). Early retirees as the next generation of entrepreneurs. Entrepreneurship: Theory and Practice, 27(3), 207-226. https://doi.org/10.1111/1540-8520.t01-1-00001

Small, M. (2012). Understanding the older entrepreneur. Working with Older People, 16(3), 132-140. https://doi.org/10.1108/13663661211260952

Smith, D. A., \& Lohrke, F. T. (2008). Entrepreneurial network development: trusting in the process. Journal of Business Research, 61(4), 315-322. https://doi.org/10.1016/j.jbusres.2007.06.018

Starr, J. A., Macmillan, I. C. (1990). Resource cooptation via social contracting: resource acquisition strategies 
for new ventures. Strategic Management Journal, 11(1), 79-92.

Subramaniam, M., \& Youndt, M. A. (2005). The influence of intellectual capital on the type of innovative capabilities. Academy of Management Journal, 48(3), 450-463. https://doi.org/10.5465/AMJ.2005.17407911

Sullivan, P. H. (1999). Profiting from intellectual capital. Journal of Knowledge Management, 3(2), 132-142. https://doi.org/10.1108/13673279910275585

Sveiby, K. E. (1997). The New Organizational Wealth: Managing and Measuring Knowledge Based Assets. San Francisco, CA: Berrett Koehler.

Tovstiga, G., \& Tulugurova, E. (2007). Intellectual capital practices and performance in Russian enterprises. Journal of Intellectual Capital, 8(4), 695-707. https://doi.org/10.1108/14691930710830846

Ucbasaran, D., Westhead, P., \& Wright, M. (2006). The Habitual Entrepreneur. Aldershot, USA: Edward Elgar Publishing Ltd.

Ucbasaran, D., Wright, M., \& Westhead, P. (2003). A longitudinal study of habitual entrepreneurs: starters and acquirers. Entrepreneurship and Regional Development, 15(3), 207-228. https://doi.org/10.1080/08985620210145009

Usman, M., Fan, L., \& Haq, M. A. U. (2016). An interpretive phenomenological study of older entrepreneurs in Pakistan. Mediterranean Journal of Social Sciences, 7(2 S1), 290-300. https://doi.org/10.5901/mjss.2016.v7n2s1p290

Weber, P., \& Schaper, M. (2004). Understanding the grey entrepreneur. Journal of enterprising culture, 12(02), 147-164. https://doi.org/10.1142/S0218495804000087

Wee, K. N. (2004). A problem-based learning approach in entrepreneurship education: Promoting authentic entrepreneurial learning. International Journal of Technology Management, 28(7/8), 685-701. https://doi.org/10.1504/IJTM.2004.005777

Westhead, P., Ucbasaran, D., \& Wright, N. M. (2005). Experience and cognition: Do novice, serial and portfolio entrepreneurs differ? International Small Business Management, 23(1), 72-98. https://doi.org/10.1177/0266242605049104

Wu, W., Chang, M., \& Chen, C. (2008). Promoting innovation through the accumulation of intellectual capital, social capital and entrepreneurial orientation. $R \& D$ Management, 38(3), 265-277. https://doi.org/10.1111/1467-9914.00120-i1

Zissimopoulos, J. M., \& Karoly, L. A. (2007). Transitions to self-employment at older ages: The role of wealth, health, health insurance and other factors. Labour Economics, 14(2), 269-295. https://doi.org/10.1016/j.labeco.2005.08.002

Zolin, R. (2015). Older entrepreneurs: do they work smarter or harder? In Australian Centre for Entrepreneurship Research Exchange Conference 2015 Proceedings (pp. 1091-1103).

\section{Copyrights}

Copyright for this article is retained by the author(s), with first publication rights granted to the journal.

This is an open-access article distributed under the terms and conditions of the Creative Commons Attribution license (http://creativecommons.org/licenses/by/4.0/). 